Article

\title{
Synergies between Renewable Energy and Flexibility Investments: A Case of a Medium-Sized Industry
}

\author{
Natapon Wanapinit *(D) and Jessica Thomsen (iD) \\ Fraunhofer Institute for Solar Energy Systems ISE, Heidenhofstrasse 2, 79110 Freiburg, Germany; \\ jessica.thomsen@ise.fraunhofer.de \\ * Correspondence: natapon.wanapinit@ise.fraunhofer.de; Tel.: +49-761-458-85221
}

Citation: Wanapinit, N.; Thomsen, J. Synergies between Renewable Energy and Flexibility Investments: A Case of a Medium-Sized Industry. Energies 2021, 14, 7753. https://doi.org/ $10.3390 /$ en14227753

Academic Editor: Ali Mehrizi-Sani

Received: 14 October 2021

Accepted: 15 November 2021

Published: 18 November 2021

Publisher's Note: MDPI stays neutral with regard to jurisdictional claims in published maps and institutional affiliations.

Copyright: (c) 2021 by the authors. Licensee MDPI, Basel, Switzerland. This article is an open access article distributed under the terms and conditions of the Creative Commons Attribution (CC BY) license (https:// creativecommons.org/licenses/by/ $4.0 /)$.

\begin{abstract}
Climate and energy policies are tools used to steer the development of a sustainable economy supplied by equally sustainable energy systems. End-users should plan their investments accounting for future policies, such as incentives for system-oriented consumption, emission prices and hydrogen economy, to ensure long-term competitiveness. In this work, the utilization of variable renewable energy and flexibility potentials in a case study of an aggregate industry is investigated. An energy concept considering PV and battery expansion, flexible production, fuel cell electric trucks (FCEV) and hydrogen production is proposed, and analysed under expected techno-economic conditions and policies of 2030 using an energy system optimization model. Under this concept, total costs and emissions are reduced by $14 \%$ and $70 \%$, respectively, compared to the business-as-usual system. The main benefit of PV investment is the lowered electricity procurement. Flexibility from schedulable manufacturing and hydrogen production increases not only the self-consumption of PV generation from $51 \%$ to $80 \%$ but also the optimal PV capacity by $41 \%$. Despite the expected cost reduction and efficiency improvement, FCEV is still not competitive to diesel trucks due to higher investment and fuel prices, i.e., its adoption increases the costs by $8 \%$. However, this is resolved when hydrogen can be produced from own surplus electricity generation. Our findings reveal synergistic effects between different potentials and the importance of enabling local business models, e.g., regional hydrogen production and storage services. The SWOT analysis of the proposed concept shows that the pursuit of sustainability via new technologies entails new opportunities and risks. Lastly, end-users and policymakers are advised to plan their investments and supports towards integration of multiple application, consumption sectors and infrastructure.
\end{abstract}

Keywords: optimization; investment; renewable energy; demand-side management; hydrogen economy

\section{Introduction}

Energy system decarbonization requires massive and rapid investments in both renewable energy (RE) and flexibility technologies [1]. Essential emission reduction measures include utilization of biomass, wind and solar energy, electrifying heat generation and transport, and replacing fossil fuels with renewable hydrogen in selected applications [1]. Flexibility - the ability to react to changes in demand and supply-accommodates effective variable RE integration, and arises from various processes, e.g., energy storage, demandside management and sector-coupling technologies [2]. Ideally, needs from the private sector based on market conditions without public supports should drive these investments.

Studies on optimal investments at a national level which consider a variety of potentials, e.g., [3-5], found that both RE and complementing flexibility investments are necessary for cost-effective and sustainable decarbonization efforts. Studies at an end-user level are sparse and often focus of selected technologies or applications. For example: [6] studied optimal sizes battery in households with PV. An optimal planning of a microgrid campus with PV and battery was evaluated in [7]. In [8], a self-sufficient energy supply concept based on local bio-waste and flexible combined heat-and-power plants was analysed. Ref. [9] studied the flexibility potential for reserve energy provision and electricity 
cost reduction in a pulp-and-paper industry. Similarly, potentials in steel production and chemical plants are studied in [10,11], respectively. Ref. [12] found that the potential to reduce primary energy and $\mathrm{CO}_{2}$ emissions of a plastic processing industry is best used when consumption, generation, distribution and storage are intelligently linked. This suggests that synergies between these potentials also exist in various end-users, and that end-users should investigate them together.

Policymakers introduce energy and climate policies to steer end-users' investment strategies towards common welfare $[13,14]$; for example, introducing $\mathrm{CO}_{2}$ prices for transport and heating fuels encourage electrification and the utilization of renewable fuels [15]. Commercial end-users should plan their long-term investment strategies carefully to stay competitive under prospective policies, i.e., to invest in new technologies at the right time, while adapting their production and energy supply towards carbon neutrality [16]. As policies are constantly changing, so do the optimal strategies and the synergetic effects of RE and flexibility. Furthermore, these synergies are likely different for each end-user group, as operating characteristics of end-users influence their investment strategies [17]. Thus, regular evaluations of investment strategies for each end-user group are crucial, both for policymakers and investors.

In this work, an energy supply concept for a medium-sized aggregate industry, a gravel plant, is proposed and evaluated. The plant is characterized by high demand for electricity and transport fuel, high RE potentials from its large vicinity and operational flexibility from semi-automated production and material storage. Aggregate industries supply construction materials, which are essential elements not only for the urbanization of developing economies but also for the global growth of climate-resilient infrastructure [18,19]. This work will answer two questions: (1) How do different investment strategies affect total costs and scope 1 and $2 \mathrm{CO}_{2}$ emissions of the plant in 2030? Scope 1 includes emissions directly from sources owned by the company. Scope 2 considers emissions related to purchased electricity [20]. (2) What are the advantages and disadvantages of the least-cost strategy for medium-sized industries? A techno-economic optimization model for distributed energy systems is used to analyse the plant and to answer the first question; the second question is answered by performing the SWOT analysis on the optimal investment strategy from the modelling results.

The contributions of this work are: The joint consideration of various investment options-namely PV, wind turbines, battery storage, demand-side management, fuel cell electric trucks and hydrogen production from electricity surplus-under a novel business model reveals their interaction. The combination of model-based and qualitative analyses provides deeper insights for operators and decision-makers. Its contribution to the knowledge on investment strategies towards sustainable productions for medium-sized industries enables more inclusive energy system transition and decarbonization.

The paper is structured as follows: Section 2 introduces the expected regulatory framework in the future. Section 3 presents the methodology. The case study is described in Section 4. Results are presented in Section 5, and are discussed in Section 6. Lastly, Section 7 concludes the paper.

\section{Background on Prospective Policies}

Energy and climate policies can affect investment strategies of industrial end-users [16]. For example, under low feed-in tariffs of variable renewable energy, investments may be intended for self-consumption. To plan a cost-effective strategy towards carbon neutrality, end-users must consider prospective policies while exploiting their renewable energy and flexibility potentials. In this section, four policies deemed influential for this planning are presented, namely, decreasing supports for renewable energy in Section 2.1, incentives for flexible consumption in Section 2.2, $\mathrm{CO}_{2}$ emission pricing in Section 2.3 and the promotion of renewable hydrogen in Section 2.4. 


\subsection{Reduction in Renewable Energy Supports}

Technological development drives down costs of variable renewable energy (VRE) generation to the point that VRE is already competitive with conventional power plants in some regions of the world [21]; as results, average prices of VRE auctions are decreasing [22]. In Germany, PV feed-in tariffs have been strongly reduced in recent years [23]; and levelized costs of wind and solar generation can compete with costs of combined-cycle gas turbines in 2030 [24].

As the development progresses, and VRE is expanded at an unprecedented pace, new challenges includes how to effectively integrate VRE into systems [25]. On the premise that VRE should recover costs via markets just like conventional generation, support schemes could interfere with market mechanisms and distort market prices from generation costs. In this regard, supports should be kept low, and feed-in premiums are preferred over feed-in tariffs [26]. Due to its similar generation profile, market values of VRE decrease as more capacities are integrated, i.e., cannibalization effect [27]. This could lead to reducing feasibility of VRE investments in coming decades. Since the reducing supports and uncertainty in market-based revenues, end-users looking to invest in their VRE potentials arguably should focus on self-consumption.

\subsection{Price-Based Incentives for Flexibility Utilization}

Flexibility potentials can be utilized explicitly via markets or implicitly via the reaction to time-varying tariffs [28]. The latter is of interest for this work. Tariff design is complex, and requires consideration of different principles, namely system sustainability, e.g., complete cost recovery, economic efficiency, e.g., cost-causality, and customer protection, e.g., transparency and simplicity. Principles may act against one another-e.g., a flat price is simple, but not cost-causal -, and must be prioritized [29]. Tariffs consist of three components, namely procurement, grid fees and taxes-and-levies [30].

Each agent in liberalized electricity markets can incentivize behaviours beneficial to their responsibility by introducing time-varying prices. Grid operators may charge higher fees during periods of congestion to deter consumption, and to reduce grid expansion in the long term [31]. For energy providers, procurement rates reflecting market prices can encourage consumption during periods with low marginal generation costs, which reduces supply costs [32].

While the ratio of capital and operational expenditures of electricity grids may vary from country-to-country, these expenditures generally involve large initial investments, which shall be recovered gradually over assets' lifetimes (30-40 years) via grid fees [33,34]. The cost structure of grid fees is conventionally based on a peak power charge and a fixed volumetric charge. As end-users evolve from a price-insensitive consumer to a flexible prosumer, this structure may not be adequate to ensure a complete cost recovery [35]. To ensure sufficient revenues for grid operators and to provide incentives for grid-friendly consumption, the structure should comprise of a fixed charge and a time-varying volumetric charge [35,36].

\subsection{Prices of $\mathrm{CO}_{2}$ Emissions}

Different political instruments to curb emissions by internalizing environmental costs exist, e.g., cap-and-trade or carbon tax. Their implementation scopes and prices vary from nation to nation [37]. Low carbon technologies required for the long-term sustainable development may not be invested if the prices are too low [38]. For comparison, clearing prices in the EU emission trading system fluctuated between 15-32 €/ton in 2020 [39]. The regulated price during the introduction phase of German emission trading system is $55 € /$ ton in 2025 [40]. Abatement costs of direct air capture without utilizing waste heat in 2020 are $222 € /$ ton [41]. Even though the future prices are uncertain, it is generally projected that prices will rise over time, cf. [15,42,43]. 


\subsection{Renewable Hydrogen Economy}

Renewable hydrogen - hydrogen produced from renewable energy-is a candidate energy carrier for many difficult-to-decarbonize applications, e.g., long-haul transport or high temperature heat generation [44]. As key technologies, e.g., electrolyzer and fuel cell, are still not cost-competitive, their research and investment require public supports with a clear target [45]. In the EU sustainability vision, the share of hydrogen in total energy demand is expected to increase from less than $2 \%$ to $14 \%$ in 2050; and $40 \mathrm{GW}$ production capacity should be regionally available by 2030 [45].

Both hydrogen fuel cell electric vehicles (FCEV) and battery electric vehicles (BEV) are essential to decarbonize land-based transport [46]. While both use electrical drive trains, their performances and costs vary. BEV is more efficient than FCEV; whereas, FCEV purchase costs are cheaper than BEV [47]. FCEV can drive further and transport more payload due to the higher energy density of hydrogen; thus, it is suited for commercial vehicles, trucks and buses [46].

\section{Methodology}

The model for the quantitative analysis is explained in Section 3.1. The SWOT framework is presented in Section 3.2.

\subsection{Energy System Model}

The techno-economic optimization model for local energy systems DISTRICT [48,49], is used to determine the optimal operation and investment strategies. Systems are represented in a regionalized and time-resolved manner, which is suitable for analyzing renewable energy and flexibility potentials. They are assumed to be price-takers. Feasible solutions adhere to operational constraints, e.g., energy balance, efficiency and transport capacities and targets, e.g., renewable energy generation. The model solves for solutions with the lowest total costs, which include costs related to investment, operation, energy import and emissions.

The utilization of end-user flexibility must consider manifold process characteristics, e.g., working hours, input/output delivery, production- targets, sequences and efficiency. A generic process model developed in [50] describes flexible processes in details, and is coupled to DISTRICT for modelling flexible production. The coupling is done by including process power consumption in the energy balance equations, and operation costs in total costs. That is, both technical and economical aspects are linked. Thus, solutions consider all potentials and constraints.

The coupled model is a mixed-integer linear program. The case study is optimized over one year in a 15-min time interval. Figure 1 shows inputs and outputs of the model relevant to this case study. In Appendix A, the model is further elaborated. Interested readers are referred to [48-50] for the full description.
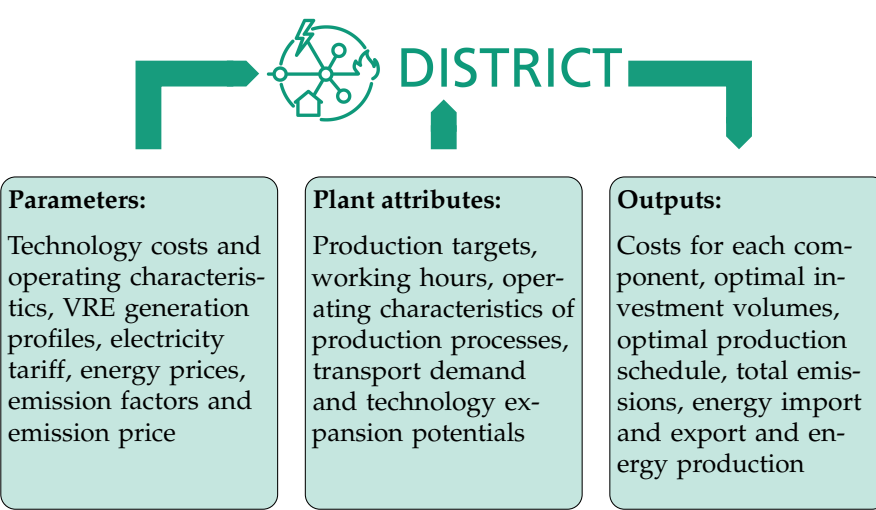

Figure 1. Simplified framework of the model. 


\subsection{SWOT Analysis}

Businesses must timely react to external and internal conditions to stay competitive. These conditions can be evaluated by the SWOT analysis. Strengths are advantageous internal conditions of the business; whereas weaknesses are disadvantageous. External factors are opportunities and threats [51]. Figure 2 presents the framework with examples.

\begin{tabular}{|c|c|c|}
\hline & Helpful & Harmful \\
\hline 胥 & $\begin{array}{l}\text { Strengths } \\
\text { e.g. special right to } \\
\text { build wind parks }\end{array}$ & $\begin{array}{c}\text { Weaknesses } \\
\text { e.g. long transport } \\
\text { distance to consumers }\end{array}$ \\
\hline 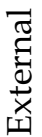 & $\begin{array}{l}\text { Opportunities } \\
\text { e.g. growing demand for } \\
\text { sustainable products }\end{array}$ & $\begin{array}{l}\text { Threats } \\
\text { e.g. stricter policies } \\
\text { on VRE land use }\end{array}$ \\
\hline
\end{tabular}

Figure 2. SWOT Framework.

With this analysis, actors can plan the launch of new initiatives, weight pros and cons of different strategies or review ongoing projects [52]. Good strategies shall rely on strengths, mitigate weaknesses, capitalize on opportunities and defend threats [51]. Note that the analysis has its limitations, such as, subjectivity of results or the lack of prioritization. In this work, the SWOT of the least-cost strategy is analysed in addition to the model-based analysis.

\section{Case Study}

The case study is a gravel plant, an energy intensive medium-sized industry, in Germany. Its operation and technical measures are described in Section 4.1. An energy concept is explained in Section 4.2. In Sections 4.3 and 4.4, scenarios and related parameters are presented.

\subsection{Description of the Plant}

The plant produces gravel with different sizes, that is delivered to customers via diesel trucks. Figure 3 shows the internal processes of the plant. The production begins with backhoes extracting raw material from an on-site artificial lake. A conveyor system transports material through out the production line. In the pre-sieving, raw material is cleaned, sorted and stored by sizes. Large gravel is broken down by stone crushers before the final sieving, where it is again cleaned and sorted. Finally, processed gravel are stored before delivery. Water pumps supply high-pressured water jet for cleaning. Auxiliary processes include product transport and energy demand for office buildings.

In status quo: No distributed energy resource is installed. The plant is automatically controlled by a production management system according to planned output while keeping the peak power under a limit. Operation planning does neither consider energy prices nor local generation. It operates 1 to 2 shifts on weekdays, which is unlike the round-the-clock operation of large industries. In the reference year 2019, the plant demands 3.7 GWh p.a. electricity for the production and $2.2 \mathrm{GWh}$ diesel for the transport fleet. On the transport demand, the fleet travels on average $2700 \mathrm{~km}$ per day, 248 days a year. Transformers connecting the plant to the medium voltage grid have a cumulative capacity of $1700 \mathrm{~kW}$, and set a limit on the power feed-in and withdrawal. Next to the plant is a 47 ha. gravel lake (German: Baggersee). 


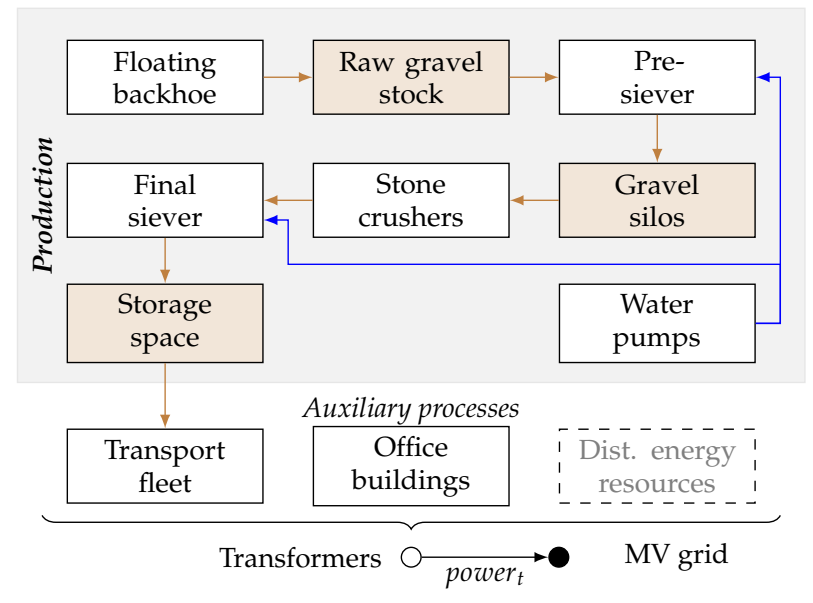

Figure 3. Internal processes of the gravel plant; brown boxes represent material storage; brown arrows represent product flows, and blue for water.

Together with the plant operators, three technical measures are identified.

Installation of energy technologies 8.3 $\mathrm{MW}_{\mathrm{p}}$ floating PV and $2 \mathrm{MWh}$ battery storage are deemed feasible. PV can produce electricity on-site, and battery can increase the self-consumption. Due to low heating demand, a combined heat-and-power plant is excluded.

Investment in a production-energy management system (PEMS) Due to embedded storage and long lead time between order and delivery, the production is flexible, i.e., it can be shifted within the same day or between adjacent days. A modern PEMS is required to utilize this potential, e.g., to react to time-varying prices.

Adoption of a low-emission transport fleet Hydrogen fuel cell electric trucks (FCEV) can replace diesel trucks for product transport. FCEV can deliver high payload over a long distance. Note that refueling stations should be available across the region in the future. Battery electric vehicles are not suitable because of limited travel distance and high tare weight.

This case study belongs to an aggregate industry sector. The sector produces varieties of products including sand, gravel and crushed rock, which are used as raw materials for construction. In Europe, the sector has over 15,000 SMEs, operates in 26,000 sites and employs over 200,000 people [53]. Overall, the sector demands electricity for mechanical processes and fuels largely for product transport, e.g., $67 \%$ primary energy consumption of a construction waste recycling plant are for the production operation, and $32 \%$ are for transportation [54]. This is similar to the energy demand of the case study.

\subsection{Energy Concept}

The case study has high electricity and transport fuel demand and high PV and flexibility potentials. The plant can reduce its energy import and $\mathrm{CO}_{2}$ emissions, and benefit from flexibility incentives. It is assumed that hydrogen production and storage capacities, distributed across Europe [45], can be rented by industrial end-users. Figure 4 presents the proposed energy concept. The concept focuses on four actors: the end-user, local hydrogen producer, local community and national energy system. Their interactions are:

1. Distributed energy resources supply internal processes with on-site electricity generation. Flexibility increases self-consumption, and allows responses to time-varying electricity prices. The production-energy management system monitors and controls all processes.

2. Electricity is imported for on-site utilization or for hydrogen production. The import is subject to procurement costs, grid fees and taxes-and-levies.

3. On-site electricity generation is fed-in, and simultaneously withdrawn for hydrogen production. Grid fees are applied. 
4. Hydrogen is produced with the electricity from (2) and (3), and stored at the production facility waiting to be tanked or (optional) transported to the end-user via a hydrogen grid. End-users may use the facility up to the rented capacities, and must pay levelized operation and investment costs. Note that idle capacities can still be used by the facility or other end-users.

5. (optional) End-users and local communities can trade surplus energy with each other.

It is assumed that end-users do not plan for electricity sale, as the goal is to be selfsufficient. Except for reacting to time-varying prices, end-users do not directly interact with grid operators or energy providers.

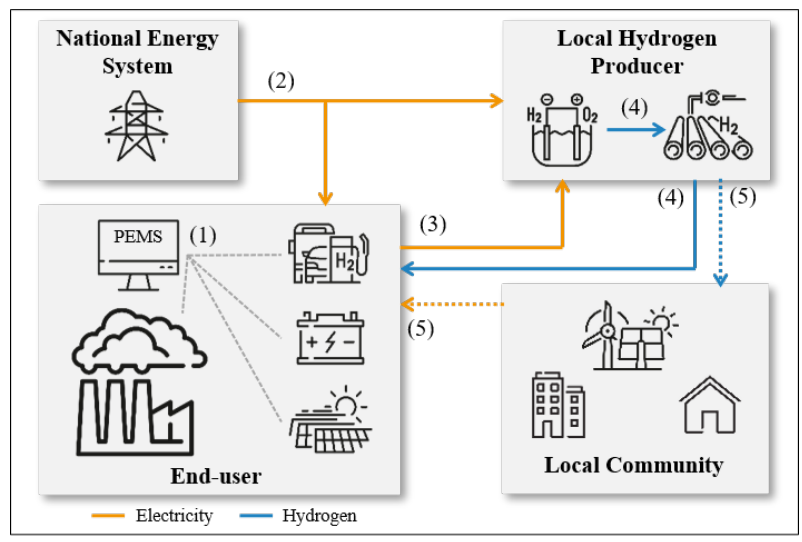

Figure 4. Proposed energy concept; solid lines represent considered interactions; dashed lines represent additional interactions.

\subsection{Scenarios}

A scenario is a framework, i.e., parameters and possible decisions, under which total costs will be minimized. Scenario names are written in typewritter font. Five scenarios are defined based on the proposed concept, and form the principle scenario set. Each scenario is built on the previous.

Business as usual BAU The plant has no energy technologies, and is inflexible. That is, the production follows the historical plan regardless of electricity prices. The transport fleet consists of diesel trucks.

Technology expansion TECH The company can invest in PV and battery.

Flexible production FLEX A production-energy management system is installed; thus, the production is flexible.

Decarbonized transport TRAN Diesel trucks are replaced by fuel cell electric trucks, which are filled by purchased hydrogen.

Local synegies SYN Hydrogen can be produced from surplus generation.

Three supplementary scenario sets are investigated to understand the effects of the peak power charge, type of renewable energy and decision year. In GFS, a grid fee structure has a fixed annual access charge accounts for 50\%, a time-varying volumetric charge $25 \%$ and a peak power charge of $25 \%$. Benefits of wind energy potential instead of solar energy are studied in WEP. In Y25, parameters for 2025 are assumed. Lastly, a sensitivity analysis is performed on the cost-optimal scenario to understand the effects of parameter uncertainties.

\subsection{Parameters}

Sources and assumptions for parameters used for the calculations are presented as follows and also in tables in Appendix B.

\subsubsection{Electricity Prices and Emission Factors}

In 2019, an average procurement rate based on EPEX prices [55] and historical consumption amounts to $4.30 \mathrm{ct} € / \mathrm{kWh}$. Grid fees interpolated from data in [56] are 
$5.65 \mathrm{ct} € / \mathrm{kWh}$. Taxes-and-levies comprise of EEG-Levy $6.41 \mathrm{ct} € / \mathrm{kWh}$ and other taxes $2.55 \mathrm{ct} € / \mathrm{kWh}$ [57]. Thus, the effective price for the case study totals to $18.90 \mathrm{ct} € / \mathrm{kWh}$.

The price projection for future years assumes that total price and other taxes remain the same. After 2022, EEG-Levy is assumed to linearly reduce to zero in 20 years. In the past five years, grid fees increase by $0.072 \mathrm{ct} € / \mathrm{kWh}$ p.a. This is assumed to continue. The procurement price is the adjusting component so that the total prices equal to $18.90 \mathrm{ct} € / \mathrm{kWh}$. Table A1 shows the projected electricity prices. [58] projected electricity prices with the same trend. On the grid fee structure, a fixed access charge contributes to $75 \%$ of grid fees, and the rest is a volumetric charge. The latter and electricity procurement are time-varying following the EPEX price profile.

A German emission factor profile for 2019 is processed from generation profiles [59] and emission factors [60] specific to power plant types. An average factor is $401 \mathrm{~g} / \mathrm{kWh}$ [60]. German emission factor is assumed to reduce by $12.0 \mathrm{~g} / \mathrm{kWh}$ p.a. This rate is derived from data in [42]. The projected average factor in 2030 is $269 \mathrm{~g} / \mathrm{kWh}$; the corresponding profile is processed by offsetting the profile for 2019 .

Figure 5 plots the volumetric price and emission profiles in 2030. Winter prices are higher than summer due to the higher demand. PV generation lowers both price and emission factor at midday; this is especially notable in summer.

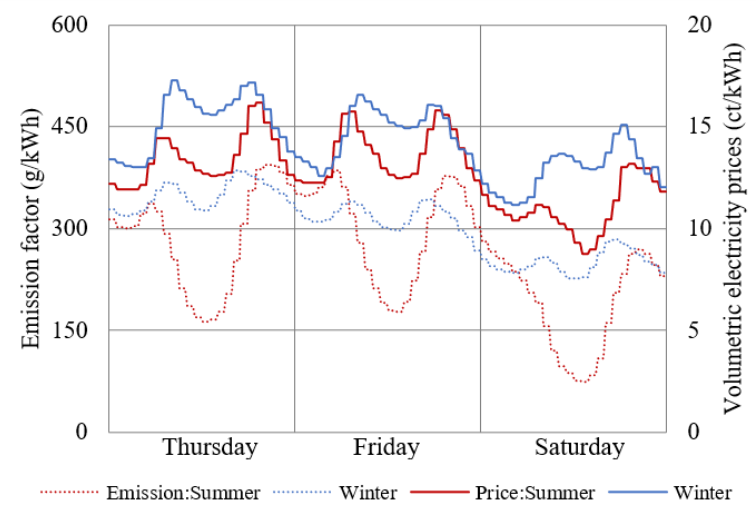

Figure 5. Average volumetric electricity prices and emission factor in summer and winter.

\subsubsection{Energy Technologies}

Investment costs for PV park and wind turbines (WT) in 2030 are 718, 550 and $1366 € / \mathrm{kWp}$ [61]. Costs for floating PV is approximately $18 \%$ higher than PV park due to the floating platform [62]. Correspondingly, floating PV price is assumed to be $660 € / \mathrm{kWp}$. On-site PV and WT generation profiles are extracted from [63] based on methods in [64,65]. The full load hours of PV generation are $1250 \mathrm{~h}$ p.a., and $1800 \mathrm{~h}$ for WT. Battery prices strongly vary by system sizes. A $150 \mathrm{kWh}$ lithium-battery system costs around $1000 € / \mathrm{kWh}$ [66] in 2019. For the projection, the cost reduction from [67] is applied, which results in the price $550 € / \mathrm{kWh}$ in 2030 . Table A2 provides more detail.

\subsubsection{Fuel Import and Emission Price}

In 2030, diesel price without emission costs is assumed to be $10.89 \mathrm{ct} / \mathrm{kWh}[68,69]$. Diesel specific emission factor is $266 \mathrm{~g} / \mathrm{kWh}$ [70]. Price of renewable hydrogen produced in Germany is $20 \mathrm{ct} / \mathrm{kWh}$ [71]. Table A3 shows hydrogen price components. Its emission factor is neglected.

Future emission prices are uncertain. [15] estimate German emission price in 2030 in the range of $80-96 € /$ ton; whereas, [42] expects a price of $140 € /$ ton. In this work, emissions are priced at $100 € /$ ton. 


\subsubsection{Hydrogen Production}

According to [71], renewable hydrogen production in 2030 has an average efficiency of $71 \%$, and a price of $20 \mathrm{ct} € / \mathrm{kWh}$. Related costs are electricity costs, investment and operation costs of equipment, and transport and distribution costs. To produce hydrogen from own electricity, end-users pay the related costs minus the electricity costs to the local hydrogen producer. These costs amount to $7.5 \mathrm{ct} € / \mathrm{kWh}$, and represent levelized costs of production, storage and distribution services. Grid fees of $1.0 \mathrm{ct} € / \mathrm{kWh}$ also apply for electricity fed-in for the hydrogen production.

In this work, the rented capacities are predetermined based on historical transport demand. The sizing criteria is the $90^{\text {th }}$ percentile of daily travel is $4074 \mathrm{~km}$, which corresponds to $8.5 \mathrm{MWh}-\mathrm{H}_{2}$ demand based on the efficiency of fuel cell electric trucks in [58]. At minimum, a $355 \mathrm{~kW}-\mathrm{H}_{2}$ electrolyser running non-stop is needed to supply this demand. It is assumed that the plant rents $3 \times 355 \mathrm{~kW}$ production and $2 \times 8.5 \mathrm{MWh}$ storage capacities. to [58].

For the transport fleet, Table A4 provides parameters on different trucks according

\section{Results}

Results are presented in three parts: an overview in Section 5.1, flexibility utilization in Section 5.2, and hydrogen production in Section 5.3. In Section 5.4, results of supplementary scenario sets are analysed. The sensitivity analysis is presented in Section 5.5.

\subsection{Overview on Costs, Emissions and Energy Technology}

Costs by component for each principle scenario are shown in Figure 6. Table 1 presents PV capacities, generation utilization, energy imports and total emissions.

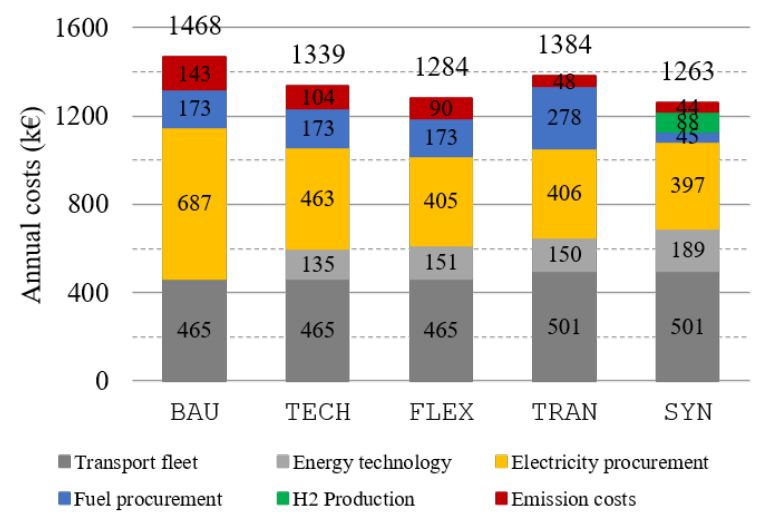

Figure 6. Costs by component of the principle scenarios.

Table 1. Optimal PV capacities and generation utilization (self-consumption, export and curtail), energy imports and emissions of the principle scenario set.

\begin{tabular}{cccccccc}
\hline \multirow{2}{*}{ Scenarios } & $\begin{array}{c}\text { Installed Capacity } \\
\left(\mathbf{M W}_{\mathbf{p}}\right)\end{array}$ & \multicolumn{2}{c}{ Generation Utilization (\%) } & \multicolumn{2}{c}{ Import (GWh) } & \multicolumn{2}{c}{ Emissions } \\
& Consume & Export & Curtail & Elec. & Fuel & (ktons) \\
\hline BAU & - & - & - & - & 3.64 & 1.58 & 1.43 \\
TECH & 2.58 & 51.0 & 47.5 & 1.5 & 1.99 & 1.58 & 1.04 \\
FLEX & 2.89 & 54.1 & 43.4 & 2.5 & 1.67 & 1.58 & 0.90 \\
TRAN & 2.87 & 54.3 & 43.3 & 2.4 & 1.68 & 1.39 & 0.48 \\
SYN & 3.63 & 80.3 & 14.0 & 5.7 & 1.64 & 0.22 & 0.44 \\
\hline
\end{tabular}

In summary, BAU has the highest costs and emissions. All measures reduce energy imports and emissions. PV and flexible production reduce costs. The switch to hydrogen fuel cell trucks (FCEV) increase costs unless hydrogen can be produced from own electricity. 
SYN has the lowest costs and emissions, $14.0 \%$ and $69.6 \%$ lower than BAU, respectively. Battery is not invested. In the following, results by scenario are described.

In BAU, the plant imports all of its energy demand, 3.64 GWh electricity and 1.58 GWh diesel p.a. This is associated with procurement costs of $687 \mathrm{k} €$ and emissions of $1.01 \mathrm{ktons}$ for electricity; and $173 \mathrm{k} €$ and $0.42 \mathrm{ktons}$ for diesel. Emission costs are $143 \mathrm{k} €$.

In TECH, 2.58 $\mathrm{MW}_{\mathrm{p}} \mathrm{PV}$ is installed, which can generate $3.23 \mathrm{GWh}$ electricity p.a. However, only $51.0 \%$ of the generation are consumed by the plant; $47.5 \%$ are exported, and $1.5 \%$ are curtailed due to the transformer limit. On-site generation significantly reduces electricity import and emissions. In comparison to BAU in Figure 6, reduced electricity and emission costs outweigh the additional energy technology costs.

In FLEX, flexible production has two benefits: First, PV potentials are better utilized, i.e., higher optimal capacity and higher self-consumption rate. Second, electricity costs are lower as consumption during periods with high prices is avoided.

In TRAN, the switch to FCEV increases the transport fleet costs and fuel procurement costs, but results in lower emissions. However, the reduced emission costs do not compensate for the increase; thus, total costs are higher in comparison to FLEX. Due to higher vehicle-to-wheel efficiency of FCEV, fuel import also decreases.

In SYN, the option to produce own hydrogen increases PV value. This results in the highest PV installation (3.63 $\mathrm{MW}_{\mathrm{p}}$ ) and self-consumption rate $(80.3 \%)$, higher than the maximum on-site utilization $\left(71.4 \%\right.$ ) (As the plant operates five days a week, $\frac{5}{7}$ of PV generation can theoretically be used.) The hydrogen import and fuel costs significantly reduce. The latter outweighs the higher energy technology costs and additional hydrogen production costs.

\subsection{Utilization of Production Flexibility}

From FLEX onward, production is intelligently scheduled; thus, electricity demand is flexible. As the electrical operation in TRAN is identical to FLEX, it is excluded from the analysis.

Figure 7 plots average electricity demand, PV generation and electricity prices. In $\mathrm{BAU}$, demand is high in the morning, and is lower in the afternoon. This is the historical inflexible production, in which the plant simply operates until storage is full or production quota is met. In FLEX, the intelligently-planned demand is shifted to midday to increase the self-consumption and to procure electricity during periods with low prices. Furthermore, the demand during early morning and evening, i.e., when prices are high, is reduced. The demand in SYN and FLEX are similar, which suggests hydrogen production and flexible production are disjointed. Note that demand cannot be shifted to night time or weekends, which leads to the weekend surplus.

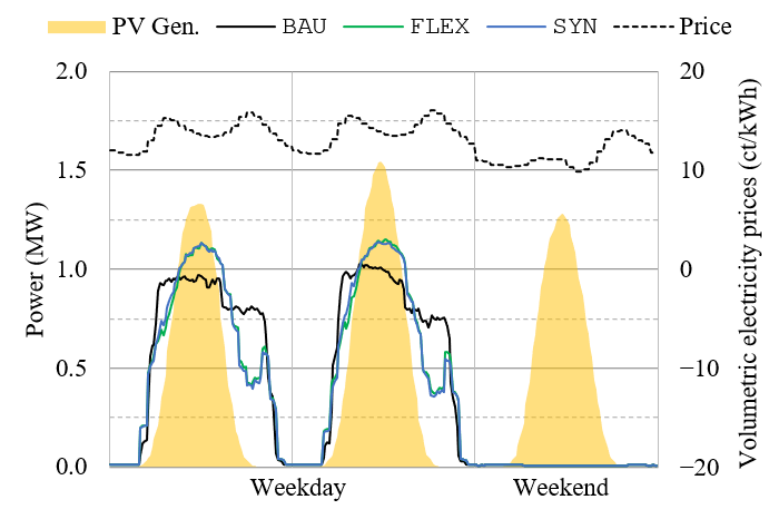

Figure 7. Average on-site electricity demand, PV generation and electricity prices of exemplary weekdays and weekend. 
Figure 8 plots average electricity import, PV generation and electricity prices. In BAU without on-site generation, electricity import represents demand and transformer losses. Comparing SYN to TECH, two benefits of production flexibility can be observed. First, on-site electricity import is lower due to higher PV utilization. Second, import during periods with high prices is notably reduced. This also results in lower average import peak power. Electricity import for hydrogen production is not subject to the working hours, and can freely react to electricity prices. Thus, it is high during night time and weekends.

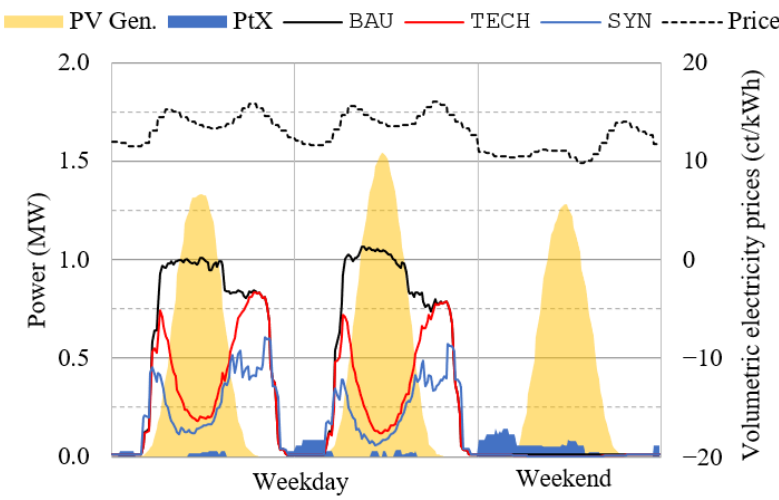

Figure 8. Average electricity import of the company, PV generation and electricity prices; PtX plots the import for the hydrogen production.

Figure 9 plots daily demand shift and change together with the planned demand. The planned demand is not uniform throughout the year. There is hardly any demand during January and February, and lower demand during summer break. Furthermore, the demand during weekends is near zero. As the planned demand limits the maximum shiftable demand, the realized demand shift and change also inherit the aforementioned pattern. In other words, production flexibility potentials depend on season and day. The total demand shift volume is 330 MWh p.a. or $9.4 \%$ of the planned demand, and demand change amounts to 193 MWh p.a. or $5.5 \%$.

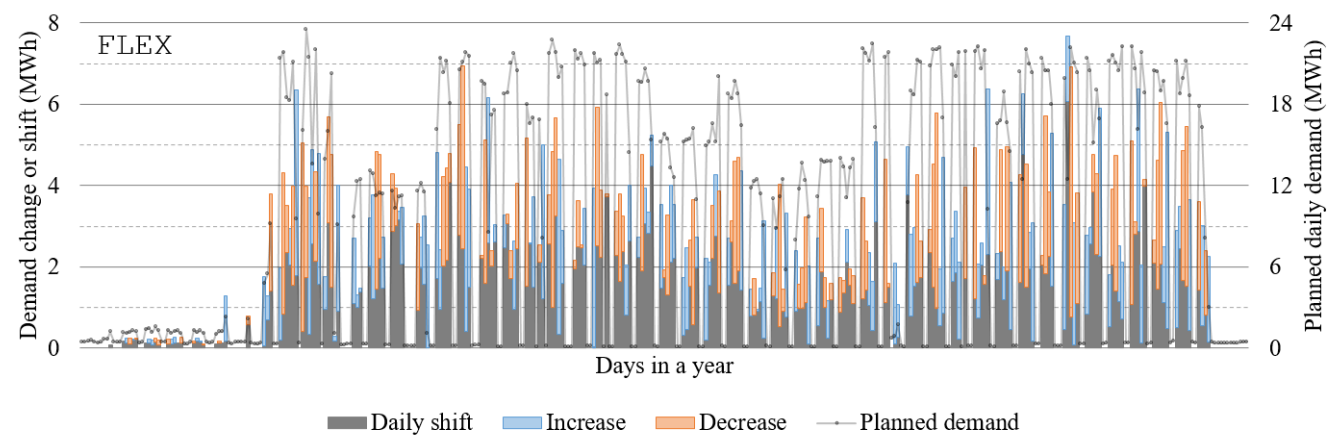

Figure 9. Volume of demand shifted from the planned operation in FLEX; grey area shows the demand shift within the same day; blue and red areas show demand change (increase and decrease, resp.) due to the shift between adjacent days.

\subsection{Hydrogen Production}

For companies committed to FCEV, the option to produce hydrogen from surplus generation is highly profitable, e.g., total costs reduce by $8.7 \%$ between TRAN and SYN. In fact, this benefits even provide financial incentives to invest in FCEV, as evidenced by the $1.6 \%$ cost reduction between FLEX and SYN.

Hydrogen produced from own electricity generation and electricity import supplies $75.5 \%$ and $8.4 \%$ of hydrogen demand (1.39 GWh p.a.), respectively. The rest, $16.1 \%$, is imported. Despite the additional electricity demand, electricity import slightly decreases. 
This is because the additional PV generation is used not only for the hydrogen production but also for on-site consumption. Figure 10 plots daily hydrogen demand, supply and average electricity prices. Hydrogen demand, an indicator for transport demand, is low during winter, as construction activities and with it the product demand are low. On the supply side: the hydrogen production from electricity import is sporadic, and occurs during days with low electricity prices. Hydrogen import is needed during late autumn and early winter, because PV generation is limited, and own production from electricity import is more expensive. Owing to the hydrogen storage, hydrogen can be produced from surplus PV generation during weekends, generation which would otherwise be exported or curtailed. The plant utilizes electrolysers for 1096 full load hours or a $12.5 \%$. On average, hydrogen storage is filled to $5.52 \mathrm{MWh}$ or $32.4 \%$. Note that actual utilization is higher, as idle capacities can be used by others.

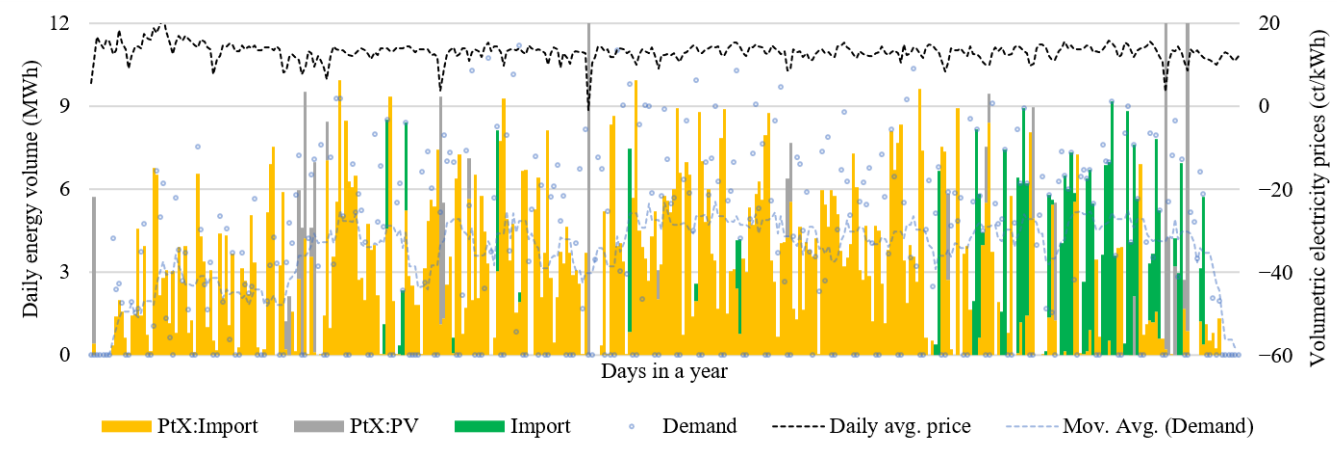

Figure 10. Daily hydrogen demand, supply and average electricity prices.

\subsection{Supplementary Scenarios}

In this section, results of supplementary sets, see Table A5 in Appendix C, are compared to the principle results, see Figure 6 and Table 1.

\section{Grid Fee Structure with Peak Power Charge (GFS)}

The peak power charge incentivizes the flexibility utilization for peak power reduction. Consequently, peak power in FLEX is $1154 \mathrm{~kW}$ lower than $1633 \mathrm{~kW}$ in the principle results. This also reduces the peak power costs by $17.1 \mathrm{k} €$ p.a. and total costs by $12.5 \mathrm{k} €$ p.a. Reduced grid fees imply lower grid operators' revenues, which may prevent full recovery of grid investment. The optimal PV capacity slightly increases so too does the self-consumption, because on-site generation can reduce peak residual load. The strategic reduction of peak feed-in leads to a higher curtailment rate and a lower self-consumption rate in SYN. Overall, investment and costs in GFS are similar to the principle results. The differences mainly lie on the operation, which can be adapted by a modern production-energy management system.

\section{Location with Only Wind Energy Potentials (WEP)}

Only in SYN, a 2.3 MW wind turbine (WT) is installed. Battery is not installed. Without on-site generation, $\mathrm{TECH}$ and BAU are identical, and production flexibility in FLEX is used only in response to time-varying electricity prices and emission factors. The latter leads to the cost reduction of $23 \mathrm{k} €$ p.a. $(1.6 \%)$, and 68 tons p.a. (4.8\%) emission reduction. Without the benefits of on-site generation, TRAN has the highest costs due to the increase from the FCEV switch. In SYN, WT generation mitigates the cost increase, as it reduces energy imports and emissions; however, SYN is not the least cost scenario, but rather FLEX.

Figure 11 plots normalized PV-, WT generation and demand, i.e., profiles are scaled to a $1 \mathrm{MWh}$ annual energy so that they are comparable. WT generation is high in winter, spring and often at night, see Figure 11a; whereas, PV generation is more seasonally and diurnally aligns with the demand, see Figure 11b. Analysing these profiles shows that the 
utilization rate of WT generation is about $31.5 \%$, and $47.2 \%$ for PV. This suggests that wind energy may not be an appropriate energy source for medium-sized end-users.

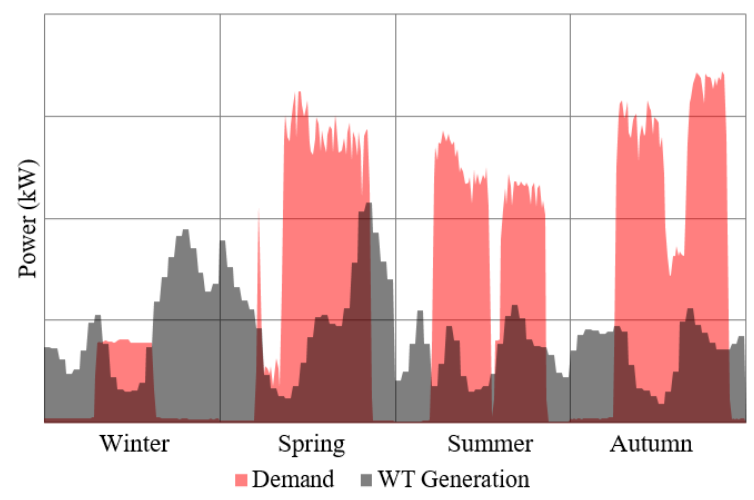

(a)

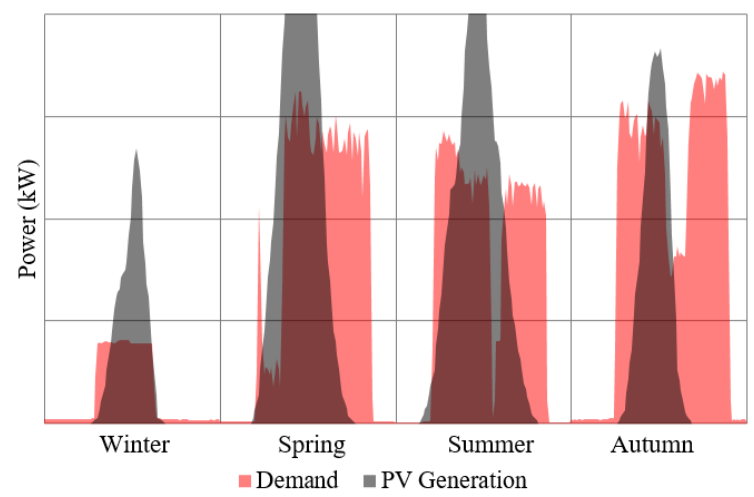

(b)

Figure 11. Normalized renewable energy generation and inflexible electricity demand of a weekday for each season; The overlapped area represents on-site utilization. (a) Wind turbine (WT) generation; (b) PV generation.

\section{Early Endeavour in Year 2025 (Y25)}

The total costs in BAU, TECH and FLEX are slightly lower than the principle results despite of the higher diesel consumption and total emissions. This is due to lower $\mathrm{CO}_{2}$ emission and diesel prices. As hydrogen technologies are relatively immature, i.e., high vehicle costs and fuel consumption of FCEV and high hydrogen import and production costs, the switch to FCEV is very costly. The cost increase in TRAN and SYN compared to FLEX are $17.8 \%$ and $6.3 \%$, compared to $7.8 \%$ and $-1.6 \%$ in 2030 . While the option to produce own hydrogen mitigates the cost increase to $6.3 \%$, companies are unlikely to accept this. Thus, FCEV switch in 2025 is unlikely without public support schemes.

\subsection{Sensitivity Analysis}

Sensitivity of the least cost scenario SYN to parameter changes is analysed. Five parameters- $\mathrm{CO}_{2}$ emission price (CEP), electricity price level (EPL), hydrogen price including costs of production and storage (HYP), PV price and operation costs (PVP) and PV yield (PVY) - are varied in the range of $\pm 20 \%$. The analysis focuses on four variables: total costs, PV installed capacity, emissions and energy import. Figure 12 presents the sensitivity analysis results.

Throughout this section, effects are considered insignificant when changes are within $\pm 1 \%$, slight $\pm 4 \%$, moderate $\pm 8 \%$ and strong for changes greater than $\pm 8 \%$. Changes in CEP have insignificant effects on all four variables. This is because the plant is insusceptible to CEP due to its low emissions. As the electricity procurement makes up $31.4 \%$ of the total 
costs, they are moderately affected by changes in EPL; However, technical variables are only slightly affected. If EPL is higher, the plant reduces its electricity import by increasing its PV installed capacity, which also reduces the $\mathrm{CO}_{2}$ emissions. The changes in HYP slightly increase the total costs; however, they insignificantly affect the technical variables. That is, the self-sufficiency from own hydrogen production protects the plant from fuel price fluctuation.

Regarding PVP and PVY, both parameters slightly affect the total costs and $\mathrm{CO}_{2}$ emissions; however, they strongly influence the optimal PV capacity. A higher PV price reduces the capacity, and increase the energy import. A higher PV yield leads to lower installed capacity and energy import. Note that variable changes are not necessarily symmetrical. For example, the decrease in PVP has greater effects on the optimal capacity and energy import than the increase.

Some parameter changes can cancel the $1.6 \%$ cost reduction between SYN and FLEX, and result in FLEX being the least cost scenario. For example, 20\% increase in HYP increases the total costs of SYN by $2.1 \%$ but does not affect the costs of FLEX.

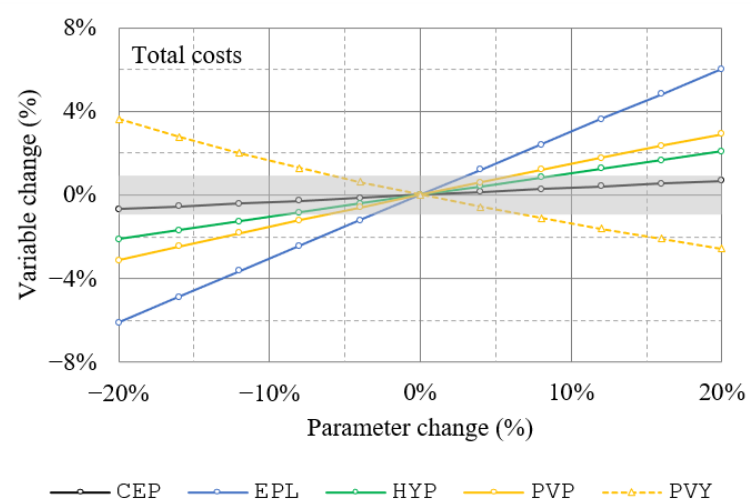

(a)

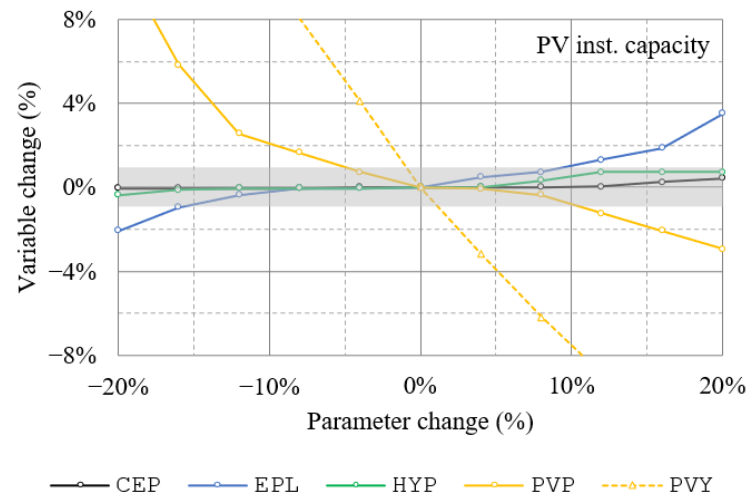

(b)

Figure 12. Cont. 


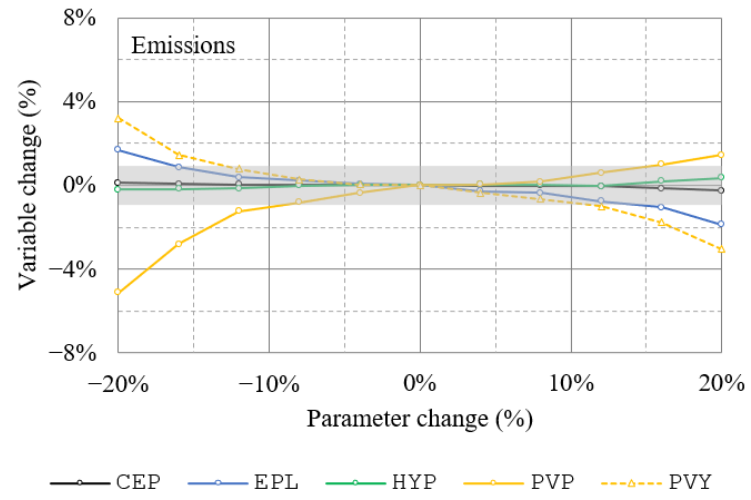

(c)

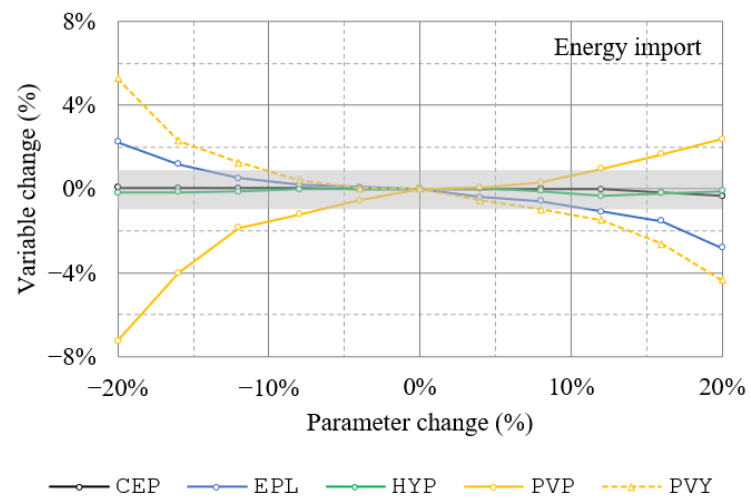

(d)

Figure 12. Effects of parameter changes to respective variables; Grey areas indicate a $\pm 1 \%$ insignificant region; $\mathrm{CO}_{2}$ emission price (CEP), electricity price (EPL), hydrogen price (HYP), PV prices (PVP) and PV yield (PVY). (a) Total costs; (b) Optimal PV installed capacity; (c) Total $\mathrm{CO}_{2}$ emissions; (d) Energy import.

\section{Discussion}

Potential implications of the proposed energy concept to end-users and the energy transition are discussed in Sections 6.1 and 6.2, respectively.

\subsection{Advantages and Disadvantages to End-Users}

The model-based analysis suggests that end-users should invest in PV, production flexibility and fuel cell electric trucks (FCEV) if hydrogen can be produced from own electricity generation. This strategy, i.e., the proposed energy concept, results in a least-cost least-emission energy system. The following presents the SWOT analysis of the concept.

Strengths

By supplying electricity demand from on-site renewable generation instead of import, end-users utilize its low-cost generation, and avoid paying grid fees, taxes-and-levies and other administrative charges. Lower energy import also means less susceptibility to energy or emission price fluctuation. Benefits of a production-energy management system, apart from increasing self-consumption and shifting demand to periods with low prices, also include reducing price risks, increasing efficiency and preemptively detecting potential problems. Lastly, the adoption of low-emission technologies can improve the company's image as technologically advanced and sustainable, which can improve its reputation to the local community, customers and investors. 


\section{Opportunities}

As public concerns over climate change grow, sustainability will be important for long term competitiveness. The company, already in the low-emission stage, can appeal its products to environmentally-conscious customers, or further offset its remaining emissions to be emission-neutral. Sales of unused generation can bring in additional revenues. The already-invested PV generation and PEMS also reduce the barriers for the utilization of power-to-heat technologies and participation in demand response programs.

\section{Weaknesses}

Initially, training for employees to operate new technologies involves additional costs and time. Installing PV in publicly-accessible area may involve permit acquisition and potential vandalism. Frequent operation changes can lead to higher maintenance costs due to extra wear-and-tear. To use own hydrogen, trucks may only be allowed to tank at designated stations, which could limit the day-to-day operation. As energy technologies, FCEV and production processes have high capital costs, simultaneous investments can lead to low financial liquidity of the firm.

\section{Threats}

The operation of FCEV may be difficult if filling stations and/or production facilities are not widely-available, e.g., due to slow transition towards the hydrogen economy. Furthermore, the regulations related to hydrogen production and storage business models are unclear; the feasibility of own hydrogen production can be reduced if taxes-and-levies are applied. Lastly, as the system relies largely on PV generation, it is susceptible to risks from fluctuating yield.

Although the model-based analysis indicates the profitability of the proposed energy concept, the SWOT analysis reveals new weaknesses and threats. The company should be aware of these disadvantages and try to mitigate them. For example, to avoid the threat from fluctuating PV yield, the company can deliberately oversize their PV systems or set up energy procurement contracts with favorable terms for uncertain consumption.

\subsection{Implication to Energy Transition}

The path towards climate-neutral energy systems has four phases: the development of renewable energy generation technologies, the integration of variable renewable energy (VRE), e.g., via direct electricity use or energy storage, the utilization of synthetic fuels and the final displacement of fossil fuels [25]. The three measures considered in this work, see Section 4.1, correspond to the first three phases.

The decarbonization of energy systems requires massive volumes of VRE investment, which must predominantly come from the private sector [72]. VRE investment has been growing in past decades given public supports and falling costs. As VRE values on saturated markets and subsidies are decreasing [22,27], the future investment is arguably to focus on self-consumption. Our results show that end-user flexibility leads not only to the higher self-consumption rate but also installed capacities. This suggests that financial or regulatory supports for flexibility investment and utilization can indirectly foster private investments in VRE.

In this work, flexible production is deployed to increase PV utilization, react to timevarying prices and reduce peak power. While flexibility potential can also provide reserve energy or interruptible load services [73], technical requirements can restrict the participation of small- and medium-sized end-users. For example in Germany, the minimum bid size of manual frequency restoration reserve, i.e., tertiary reserve, is one MW with a four-hours stand-by period [74]. Although pooling is allowed, it may not be an effective mean. Alternatively, regional markets can open up marketing opportunities for these potentials. In the project WindNODE, a market concept aimed to coordinate flexibility potentials to mitigate grid congestion is proposed and tested. In this concept, a minimum 
bid is $100 \mathrm{~kW}$ in size and 15 minutes in duration [75]. Potential revenues and benefits to energy systems from future markets should be investigated further.

Despite its higher efficiency and lower emissions, the switch to fuel cell electric trucks (FCEV) increases the costs due to high vehicle and fuel prices; this is observed in both 2025 and also 2030 albeit to a lesser extent. The use of synthetic fuels in transport would likely need a higher emission price, subsidies for vehicle investments or fuel procurement. Furthermore, the feasibility of FCEV in the long term can be improved by extensive supports in fuel cell research, which would reduce price and increase efficiency.

The switch to FCEV could be economical when hydrogen can be produced from own electricity generation. This is mainly because the company has significant electricity surplus which would otherwise be curtailed or exported at marginal prices. Despite having to pay for grid fees and production and storage costs, own hydrogen production is cheaper than hydrogen import to the point that this combination is more economic than the use of diesel trucks. Arguably, end-users not blessed with on-site VRE potentials could benefit from these benefits as well by directly purchasing surplus electricity from external sources, e.g., local communities as shown in Figure 4 or own off-site VRE investments. Both cases are similar from the perspective of the national climate goal, namely, VRE and FCEV are invested by private sectors and renewable hydrogen is produced inland. This shows that novel business models can promote investments in sustainable technologies by linking generation and demand from different sectors and various agents in the systems.

In this work, a time-resolved optimization model is used to plan the investments and operation of a company. Noteworthy cautions of this application are: Various data-e.g., operation profiles of the company or techno-economics parameters of an energy system or technologies-are required in detail; however, information may not be easily accessible or available in all cases. As the investigation scope involves flexibility and its response to time-varying electricity prices, these efforts are deemed necessary. The optimization assumes a perfect foresight on parameters. This certainly does not reflect the reality where politics and markets constantly change. The sensitivity analysis partially addresses the robustness of results to parameter changes. In the future, more extensive models, such as stochastic programs, can also account the decisive uncertainties.

\section{Conclusions}

An energy concept for an industrial end-user with renewable energy and flexibility potentials - PV plant, battery storage, flexible production, FCEV and hydrogen production - is analysed. Different investment strategies are investigated. PV is a highly profitable investment as it reduces electricity import and emission costs. Flexible production reduces costs by shifting the production to periods with low electricity prices and increasing the utilization of PV generation. The switch from diesel to hydrogen for product transport is not economical due to higher fuel and vehicle costs, unless hydrogen can be produced from own surplus electricity generation. The synergistic benefits of both potentials lead to the least-cost least-emission system.

End-users are advised to consider both potentials in the planning process to ensure that a strategy is optimal in the long term. The cost optimal investment strategy entails new risks and opportunities from the changing energy politics and the adoption of new technologies. For example, heavy reliance on PV generation implies susceptibility to uncertain PV yield. Carbon-neutral industrial end-users can appeal its products to environmentallyconscious customers.

The pathway towards sustainable energy systems requires not only supports for the $\mathrm{R} \& \mathrm{D}$ or the adoption of new technologies but also new incentives-e.g, time-varying electricity prices for flexibility or $\mathrm{CO}_{2}$ prices for decarbonization-and enabling business models. Case in point, the switch to FCEV is promoted by the higher fossil fuel prices and by own hydrogen production via a regional hydrogen facility. Early regulatory adjustments, e.g., tax exemptions for own hydrogen production, can accelerate the adoption in easilyachievable cases. Next generation energy policies should couple supports for flexibility 
and renewable energy expansion to transition towards integrated energy systems with coordination of multiple applications, sectors and infrastructures.

On the limitations of this work: as policies are constantly changing, the absolute results are subject to uncertainties of the future development. Each end-user group has unique potentials and requirements. It stands to reason that synergies between both potentials exist in all users; nevertheless, studies similar to this for other end-users are advised to gauge the effects and to gain insights into optimal investment behaviours. Energy efficiency measures should also be considered.

Author Contributions: Conceptualization, N.W.; methodology, N.W. and J.T.; software, N.W.; validation, N.W.; formal analysis, N.W.; investigation, N.W.; data curation, N.W.; writing-original draft, N.W. and J.T.; writing-review \& editing, N.W. and J.T.; visualization, N.W.; supervision, J.T.; project administration, J.T.; and funding acquisition, N.W. and J.T. All authors have read and agreed to the published version of the manuscript.

Funding: This work is a part of the main author's doctoral dissertation supported by the German Federal Environmental Foundation, and was carried out under the project FlexGeber sponsored by the German Ministry of Economics and Energy under the grant 03EGB0001A.

Institutional Review Board Statement: Not applicable.

Informed Consent Statement: Not applicable.

Data Availability Statement: The data acquired and/or generated for the study are not publicly available due to privacy concerns, but may be available on reasonable request.

Conflicts of Interest: The authors declare no conflict of interest.

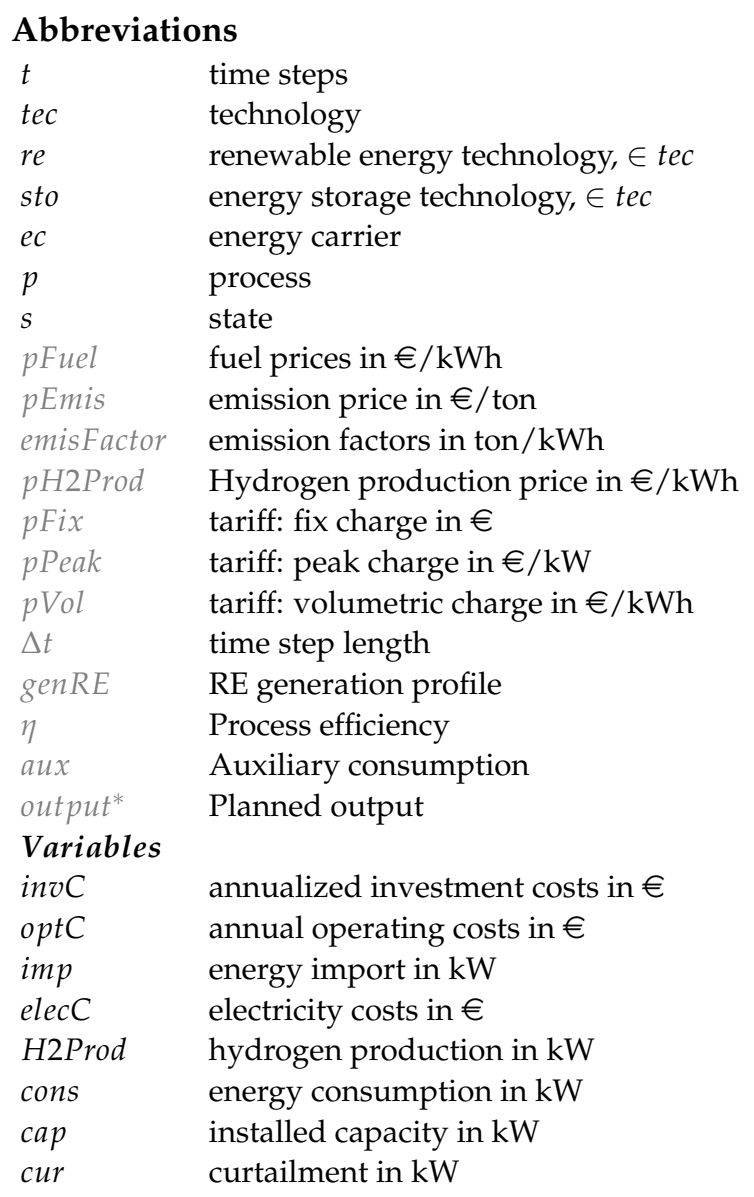




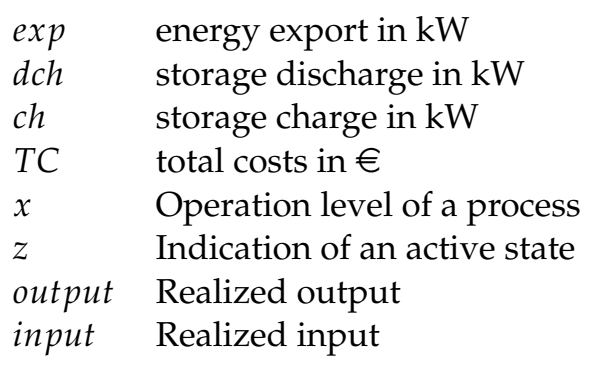

\section{Appendix A}

In this appendix, fundamental functions of the model in Section 3.1 are further clarified. Symbols are listed in the abbreviations. Subscripts refer to indices. Parameters are written in gray.

The optimization objective is to minimize the total costs (TC) described in Equation (A1). TC includes: (1) annualized investment costs (invC) and operation costs of energy technologies and flexible processes $(o p t C),(2)$ costs of fuel import (imp) according to fuel prices ( $p$ Fuel) and costs of electricity import (elecC), (3) emission costs from energy import parameterized by emission price ( $p$ Emis) and emission factor (emisFactor), and (4) costs of hydrogen production.

$$
\begin{aligned}
& \min T C:=\sum_{t e c}\left(i n v C_{t e c}+o p t C_{t e c}\right)+\sum_{\text {pro }}\left(o p t C_{\text {pro }}\right) \\
& +\sum_{t, e c-\{e l\}}\left(p \text { Fuel }_{e c} \cdot \Delta t \cdot i m p_{t, e c}\right)+e l e c C \\
& +p \text { Emis } \cdot \sum_{t, e c}\left(\text { emisFactor }_{t, e c} \cdot \Delta t \cdot \text { imp }_{e c, t}\right) \\
& +p H 2 \operatorname{Prod} \cdot \Delta t \cdot \sum_{t} H 2 \operatorname{Prod}_{t}
\end{aligned}
$$

In Equation (A2), elecC is calculated according to the three parts of an electricity tariff, namely fixed charge $(p F i x)$, peak charge $(p P e a k)$ and volumetric charge $(p V o l)$.

$$
\text { elecC }=p \text { Fix }+p \text { Peak } \cdot \max _{t} i m p_{e l, t}+\sum_{t}\left(p V o l_{t} \cdot \Delta t \cdot i m p_{e l, t}\right)
$$

Equation (A3) represents the energy balance, in which, the consumption (cons) of an energy carrier of all processes must be balanced with the renewable energy generation characterized by generation profiles ( $g e n R E)$ and installed capacity (cap), curtailment (cur), exchange with external system (imp and $\exp$ ) and the utilization of energy storage ( $d c h$ and $c h$ ). cap is limited by the technology potentials; similarly, imp and exp are limited by transformer capacities.

$$
\begin{aligned}
\sum_{\text {pro }} \text { cons }_{\text {pro }, e c, t}= & \sum_{r e}\left(g e n R E_{r e, e c, t} \cdot \operatorname{cap} p_{r e, e c, t}-\operatorname{cur}_{r e, e c, t}\right) \\
& +i m p_{e c, t}-\exp _{e c, t} \\
& +\sum_{\text {sto }}\left(d c h_{s t o, e c, t}-c h_{s t o, e c, t}\right)
\end{aligned}
$$

End-user flexibility is modelled by a generic process model which accounts both the technical characteristics, e.g, production capacity or storage capacity, and operational constraints, e.g., working hours or production targets. In this framework, every process has a multi-states conversion unit, the machine. The instantaneous consumption is related to the operation level $(x \in[0,1])$, efficiency $(\eta)$ and auxiliary consumption (aux) of an active state indicated by the binary variable $z \in\{0,1\}$. Equation (A4) shows the relation for electricity; analogous equations also exist for input and output. 


$$
\text { cons }_{p, e l, t}=\sum_{s}\left(\eta_{p, s} \cdot x_{p, s, t}+a u x_{p, s} \cdot z_{p, s, t}\right)
$$

In Equation (A5), the realized output (output) is related to the planned output (output*) and deviation options, namely output increase or decrease $(O I D)$ and output shift within the same day or between adjacent days (OSW and OSB).

$$
\text { output }_{p, t}=\text { output }_{p, t}^{*}+O I D_{p, t}+O S W_{p, t}+O S B_{p, t}
$$

Input and output of dependent processes are linked via a constraint: output $_{p_{1}, t}=$ input $_{p_{2}, t} \mid p_{1}, p_{2} \in p$.

A procedure to model the floating backhoe process is as follows: From the site visit, it is noted that the process has two operating states: on and off. Working hours, the maximum capacity and the operation range in the on state are defined from the historical load profile and statements from plant operators. It is then established that the process can be operated from $06: 00-22: 00$ and at loading capacity from $75 \%$ to $100 \%$. Power consumption at the maximum loading capacity is $110 \mathrm{~kW}$. Based on these characteristics, the planned operation is the operating profile which is best fit to the historical load profile. The procedure is repeated for all processes.

\section{Appendix B}

Table A1 shows electricity prices. Table A2 presents costs of energy technologies. Table A3 shows costs of renewable hydrogen by components. And Table A4 shows costs and efficiency of different trucks.

Table A1. Electricity prices by components.

\begin{tabular}{llll}
\hline Parameters & $\mathbf{2 0 1 9}$ & $\mathbf{2 0 2 5}$ & $\mathbf{2 0 3 0}$ \\
\hline Procurement & 4.30 & 4.83 & 7.31 \\
Grid fees & 5.65 & 6.08 & 6.44 \\
EEG Levy & 6.41 & 5.44 & 3.84 \\
Other taxes & 2.55 & 2.55 & 2.55 \\
\hline Total & 18.90 & 18.90 & 18.90 \\
\hline
\end{tabular}

Table A2. Costs and lifetime of energy technologies.

\begin{tabular}{lllll}
\hline Technology & Parameter & $\mathbf{2 0 2 0}$ & $\mathbf{2 0 2 5}$ & $\mathbf{2 0 3 0}$ \\
\hline Rooftop PV & Investment (€/kWp) & 976 & 847 & 718 \\
& OPEX (\% CAPEX p.a.) & 2 & 2 & 2 \\
& Lifetime & 26 & 27 & 27 \\
\hline Floating PV & Investment (€/kWp) & 778 & 719 & 660 \\
& OPEX (\% CAPEX p.a.) & 2 & 2 & 2 \\
& Lifetime & 26 & 27 & 27 \\
\hline \multirow{2}{*}{ Wind turbine } & Investment (€/kWp) & 1493 & 1430 & 1366 \\
& OPEX (\% CAPEX p.a.) & 3 & 3 & 3 \\
& Lifetime & 24 & 25 & 25 \\
\hline Battery & Investment (€/kWh) & 870 & 650 & 550 \\
& OPEX (\% CAPEX p.a.) & 1 & 1 & 1 \\
& Lifetime & 10 & 12 & 15 \\
\hline
\end{tabular}


Table A3. Price components of green hydrogen produced in Germany according to [71].

\begin{tabular}{llll}
\hline Parameters & $\mathbf{2 0 2 0}$ & $\mathbf{2 0 2 5}$ & $\mathbf{2 0 3 0}$ \\
\hline Electricity costs & 17.0 & 14.8 & 12.5 \\
Transport costs & 1.9 & 1.9 & 1.9 \\
CAPEX/OPEX & 7.3 & 6.4 & 5.6 \\
\hline Total & 26.2 & 23.1 & 20.0 \\
\hline
\end{tabular}

Table A4. Costs and fuel efficiency of diesel trucks and fuel cell electric trucks according to [58].

\begin{tabular}{lllll}
\hline Types & Parameters & $\mathbf{2 0 2 0}$ & $\mathbf{2 0 2 5}$ & $\mathbf{2 0 3 0}$ \\
\hline Diesel & Investment $(\mathrm{t} €)$ & 80 & 86 & 88 \\
& Maintenance $(\mathrm{K} €$ p.a. $)$ & 18 & 18 & 18 \\
& Efficiency $(\mathrm{kWh} / 100 \mathrm{~km})$ & 328 & 268 & 238 \\
\hline FCEV & Investment $(\mathrm{t} €)$ & 174 & 126 & 110 \\
& Maintenance $(\mathrm{K} €$ p.a. $)$ & 30 & 16 & 16 \\
& Efficiency $(\mathrm{kWh} / 100 \mathrm{~km})$ & 272 & 230 & 209 \\
\hline
\end{tabular}

\section{Appendix C}

Table A5 presents results of the supplementary scenarios.

Table A5. Total costs, optimal capacities and generation utilization, energy imports and emissions of the supplementary scenarios.

\begin{tabular}{|c|c|c|c|c|c|c|c|c|c|}
\hline \multirow{2}{*}{\multicolumn{2}{|c|}{ Set:Scenarios }} & \multirow{2}{*}{$\begin{array}{l}\text { Total Costs } \\
\quad(\mathbf{k} \in)\end{array}$} & \multirow{2}{*}{$\begin{array}{c}\text { Installed Capacity } \\
\left(\mathrm{MW}_{\mathrm{p}}\right)\end{array}$} & \multicolumn{3}{|c|}{ Generation Utilization (\%) } & \multicolumn{2}{|c|}{ Import (GWh) } & \multirow{2}{*}{$\begin{array}{c}\text { Emissions } \\
\text { (ktons) }\end{array}$} \\
\hline & & & & Consume & Export & Curtail & Elec. & Fuel & \\
\hline \multirow{5}{*}{ GFS : } & BAU & 1468 & - & - & - & - & 3.64 & 1.58 & 1.43 \\
\hline & $\mathrm{TECH}$ & 1338 & 2.60 & 52.1 & 46.2 & 1.7 & 1.94 & 1.58 & 1.03 \\
\hline & FLEX & 1271 & 2.93 & 54.6 & 38.1 & 7.3 & 1.62 & 1.58 & 0.90 \\
\hline & TRAN & 1371 & 2.93 & 54.6 & 38.1 & 7.3 & 1.62 & 1.39 & 0.48 \\
\hline & SYN & 1253 & 3.66 & 79.5 & 8.3 & 12.2 & 1.64 & 0.24 & 0.44 \\
\hline \multirow{5}{*}{ WEP : } & BAU & 1468 & - & - & - & - & 3.64 & 1.58 & 1.43 \\
\hline & $\mathrm{TECH}$ & 1468 & 0 & 0 & 0 & 0 & 3.64 & 1.58 & 1.43 \\
\hline & FLEX & 1445 & 0 & 0 & 0 & 0 & 3.64 & 1.58 & 1.37 \\
\hline & TRAN & 1545 & 0 & 0 & 0 & 0 & 3.64 & 1.39 & 0.95 \\
\hline & SYN & 1488 & 2.30 & 70.2 & 28.6 & 1.2 & 2.34 & 0.28 & 0.59 \\
\hline \multirow{5}{*}{ Y25: } & BAU & 1425 & - & - & - & - & 3.64 & 1.78 & 1.71 \\
\hline & TECH & 1314 & 2.40 & 52.7 & 46.3 & 1.1 & 2.05 & 1.78 & 1.23 \\
\hline & FLEX & 1267 & 2.71 & 55.8 & 42.6 & 1.7 & 1.73 & 1.78 & 1.08 \\
\hline & TRAN & 1493 & 2.71 & 55.8 & 42.5 & 1.7 & 1.73 & 1.53 & 0.61 \\
\hline & SYN & 1347 & 3.75 & 81.2 & 12.9 & 5.8 & 1.61 & 0.27 & 0.53 \\
\hline
\end{tabular}

\section{References}

1. International Energy Agency. Net Zero by 2050: A Roadmap for the Global Energy Sector. Available online: https:/ / www.iea.org/ reports / net-zero-by-2050 (accessed on 10 October 2021).

2. Cochran, J.; Miller, M.; Zinaman, O.; Milligan, M.; Arent, D.; Palmintier, B.; Mueller, S. Flexibility in 21st Century Power Systems. Available online: https://www.nrel.gov/docs/fy14osti/61721.pdf (accessed on 10 october 2021).

3. Kost, C.; Brandes, J.; Senkpiel, C.; Sterchele, P.; Wrede, D.; Henning, H.M. Modeling of Persistence, Non-Acceptance and Sufficiency in Long-Term Energy Scenarios for Germany. Energies 2021, 14, 4484. [CrossRef]

4. Yue, X.; Patankar, N.; DeCarolis, J.; Chiodi, A.; Rogan, F.; Deane, J.P.; O'Gallachoir, B. Least cost energy system pathways towards 100\% renewable energy in Ireland by 2050. Energy 2020, 207, 118264. [CrossRef]

5. Anasis, J.G.; Khalil, M.A.K.; Butenhoff, C.; Bluffstone, R.; Lendaris, G.G. Optimal energy resource mix for the US and China to meet emissions pledges. Appl. Energy 2019, 238, 92-100. [CrossRef]

6. Mulleriyawage, U.; Shen, W.X. Optimally sizing of battery energy storage capacity by operational optimization of residential PV-Battery systems: An Australian household case study. Renew. Energy 2020, 160, 852-864. [CrossRef] 
7. Husein, M.; Chung, I.Y. Optimal design and financial feasibility of a university campus microgrid considering renewable energy incentives. Appl. Energy 2018, 225, 273-289. [CrossRef]

8. Petersen, J.P. Energy concepts for self-supplying communities based on local and renewable energy sources: A case study from northern Germany. Sustain. Cities Soc. 2016, 26, 1-8. [CrossRef]

9. Helin, K.; Käki, A.; Zakeri, B.; Lahdelma, R.; Syri, S. Economic potential of industrial demand side management in pulp and paper industry. Energy 2017, 141, 1681-1694. [CrossRef]

10. Ramin, D.; Spinelli, S.; Brusaferri, A. Demand-side management via optimal production scheduling in power-intensive industries: The case of metal casting process. Appl. Energy 2018, 225, 622-636. [CrossRef]

11. Xenos, D.P.; Mohd Noor, I.; Matloubi, M.; Cicciotti, M.; Haugen, T.; Thornhill, N.F. Demand-side management and optimal operation of industrial electricity consumers: An example of an energy-intensive chemical plant. Appl. Energy 2016, 182, 418-433. [CrossRef]

12. Dunkelberg, H.; Wagner, J.; Hannen, C.; Schlüter, B.A.; Phan, L.; Hesselbach, J.; Lin, C.X. Optimization of the energy supply in the plastics industry to reduce the primary energy demand. J. Clean. Prod. 2018, 192, 790-800. [CrossRef]

13. Hong, L.; Zhou, N.; Fridley, D.; Raczkowski, C. Assessment of China's renewable energy contribution during the 12th Five Year Plan. Energy Policy 2013, 62, 1533-1543. [CrossRef]

14. European Commission. Report on the Functioning of the European Carbon Market: COM(2020) 740 Final. Available online: https:/ / eur-lex.europa.eu/legal-content/EN/TXT/?uri=CELEX\%3A52020DC0740 (accessed on 5 October 2021).

15. Hennes, O.; Jeddi, S.; Madlener, R.; Schmitz, H.; Wagner, J.; Wolff, S.; Zinke, J. Auswirkungen von $\mathrm{CO}_{2}$-Preisen auf den Gebäude-, Verkehrs- und Energiesektor. Z. FüR Energiewirtschaft 2021, 45, 91-107. [CrossRef]

16. Obrist, M.D.; Kannan, R.; Schmidt, T.J.; Kober, T. Decarbonization pathways of the Swiss cement industry towards net zero emissions. J. Clean. Prod. 2021, 288, 125413. [CrossRef]

17. Wesseling, J.H.; Lechtenböhmer, S.; Åhman, M.; Nilsson, L.J.; Worrell, E.; Coenen, L. The transition of energy intensive processing industries towards deep decarbonization: Characteristics and implications for future research. Renew. Sustain. Energy Rev. 2017, 79, 1303-1313. [CrossRef]

18. Bai, X.; Dawson, R.J.; Ürge-Vorsatz, D.; Delgado, G.C.; Salisu Barau, A.; Dhakal, S.; Dodman, D.; Leonardsen, L.; Masson-Delmotte, V.; Roberts, D.C.; et al. Six research priorities for cities and climate change. Nature 2018, 555, 23-25. [CrossRef] [PubMed]

19. Mullan, M.; Danielson, L.; Lasfargues, B.; Morgado, N.C.; Perry, E. Climate-Resilient Infrastructure: Policy Perspectives OECD Environment Policy Paper. Available online: https://www.oecd.org/environment/cc/policy-perspectives-climate-resilientinfrastructure.pdf (accessed on 1 October 2021).

20. World Business Council for Sustainable Development, World Resources Institute. The Greenhouse Gas Protocol: A Corporate Accounting and Reporting Standard; World Business Council for Sustainable Development and World Resources Institute: Geneva, Switzerland; Washington, DC, USA, 2004.

21. Gielen, D.; Boshell, F.; Saygin, D.; Bazilian, M.D.; Wagner, N.; Gorini, R. The role of renewable energy in the global energy transformation. Energy Strategy Rev. 2019, 24, 38-50. [CrossRef]

22. International Renewable Energy Agency. Renewable Energy Auctions: Analysing; 2016. Available online: https://www.irena.org/ publications / 2017/Jun/Renewable-Energy-Auctions-Analysing-2016 (accessed on 23 September 2021).

23. Wirth, H. Recent Facts about Photovoltaics in Germany. Available online: https://www.ise.fraunhofer.de/en/publications/ studies / recent-facts-about-pv-in-germany.html (accessed on 15 September 2021).

24. Kost, C.; Shammugam, S.; Fluri, V.; Peper, D.; Davoodi Memar, A.; Schlegl, T. Levelized Cost of Electricity Renewable Energy Technologies. Available online: https://www.ise.fraunhofer.de/content/dam/ise/en/documents/publications/studies/EN2 021_Fraunhofer-ISE_LCOE_Renewable_Energy_Technologies.pdf (accessed on 15 August 2021).

25. Leopoldina, A.; Union der Deutschen Akademien der Wissenschaften. Coupling the Different Energy Sectors-Options for the Next Phase of the Energy Transition. Available online: https:/ /www.akademienunion.de/publikation/coupling-the-differentenergy-sectors-options-for-the-next-phase-of-the-energy-transition (accessed on 20 October 2021).

26. Winkler, J.; Gaio, A.; Pfluger, B.; Ragwitz, M. Impact of renewables on electricity markets—Do support schemes matter? Energy Policy 2016, 93, 157-167. [CrossRef]

27. Pape, C. The impact of intraday markets on the market value of flexibility-Decomposing effects on profile and the imbalance costs. Energy Econ. 2018, 76, 186-201. [CrossRef]

28. Smart Energy Demand Coalition. Explicit and Implicit Demand-Side Flexibility: Complementary Approaches for an Efficient Energy System. Available online: https:/ / www.smarten.eu/wp-content/uploads/2016/09/SEDC-Position-paper-Explicit-andImplicit-DR-September-2016.pdf (accessed on 17 September 2021).

29. Picciariello, A.; Reneses, J.; Frias, P.; Söder, L. Distributed generation and distribution pricing: Why do we need new tariff design methodologies? Electr. Power Syst. Res. 2015, 119, 370-376. [CrossRef]

30. Eid, C.; Koliou, E.; Valles, M.; Reneses, J.; Hakvoort, R. Time-based pricing and electricity demand response: Existing barriers and next steps. Util. Policy 2016, 40, 15-25. [CrossRef]

31. REF-E; Mercados; Indra. Study on Tariff Design for Distribution Systems: Final Report Prepared for Directorate-General for Energy of the European Commission. Available online: https://ec.europa.eu/energy/sites/ener/files/documents/20150313\%2 0Tariff\%20report\%20fina_revREF-E.PDF (accessed on 3 October 2021). 
32. Finn, P.; Fitzpatrick, C. Demand side management of industrial electricity consumption: Promoting the use of renewable energy through real-time pricing. Appl. Energy 2014, 113, 11-21. [CrossRef]

33. Ofgem. International Review of Cost Recovery Issues. Available online: https://www.ofgem.gov.uk/sites/default/files/docs/ 2017/03/cepa_tnei_international_review_of_cost_recovery_issues_final_report.pdf (accessed on 24 April 2021).

34. Hesamzadeh, M.; Rosellón, J.; Vogelsang, I. Transmission Network Investment in Liberalized Power Markets; Lecture notes in energy; Springer: Cham, Switzerland, 2020; Volume 79.

35. Borenstein, S. The economics of fixed cost recovery by utilities. Electr. J. 2016, 29, 5-12. [CrossRef]

36. Fritz, W.; Willemsen, S.; Linke, C.; Klobasa, M. Optionen zur Weiterentwicklung der Netzentgeltsystematik für Eine Sichere, Umweltgerechte und Kosten Effiziente Energiewende. Available online: http://publica.fraunhofer.de/dokumente/N-555070 .html (accessed on 14 August 2021).

37. Narassimhan, E.; Gallagher, K.S.; Koester, S.; Rivera Alejo, J. Carbon Pricing in Practice: A Review of the Evidence. Available online: https: / sites.tufts.edu/cierp/files/2017/11/Carbon-Pricing-In-Practice-A-Review-of-the-Evidence.pdf (accessed on 21 September 2021).

38. Brink, C.; Vollebergh, H.R.; van der Werf, E. Carbon pricing in the EU: Evaluation of different EU ETS reform options. Energy Policy 2016, 97, 603-617. [CrossRef]

39. European Commission. Report on the Functioning of the European Carbon Market in 2020: COM(2021) 962 Final. Available online: https:/ / eur-lex.europa.eu/legal-content/EN/TXT/?uri=CELEX\%3A52021DC0962\&qid=1635437877783 (accessed on 3 October 2021).

40. Umweltbundesamt. Nationales Emissionshandelssystem: Hintergrundpapier. Available online: https://www.dehst.de/ SharedDocs/downloads/DE/nehs/nehs-hintergrundpapier.pdf?_blob=publicationFile\&v=3 (accessed on 3 October 2021).

41. Fasihi, M.; Efimova, O.; Breyer, C. Techno-economic assessment of $\mathrm{CO}_{2}$ direct air capture plants. J. Clean. Prod. 2019, 224, 957-980. [CrossRef]

42. Prognos. Energiewirtschaftliche Projektionen und Folgeabschätzungen 2030/2050: Dokumentation von Referenzszenario und Szenario mit Klimaschutzprogramm 2030. Available online: https:/ /www.prognos.com/de/projekt/energiewirtschaftlicheprojektionen-20302050 (accessed on 10 October 2021).

43. Hänsel, M.C.; Drupp, M.A.; Johansson, D.J.A.; Nesje, F.; Azar, C.; Freeman, M.C.; Groom, B.; Sterner, T. Climate economics support for the UN climate targets. Nat. Clim. Chang. 2020, 10, 781-789. [CrossRef]

44. International Energy Agency. The Future of Hydrogen: Seizing Today's Opportunities: Report Prepared by the IEA fro the G20, Japan. Available online: https:/ / www.iea.org/reports/the-future-of-hydrogen (accessed on 29 July 2021).

45. European Commission. A Hydrogen Strategy for a Climate-Neutral EUROPE: COM(2020) 301 Final. Available online: https: / / ec.europa.eu/energy / sites/ener/files/hydrogen_strategy.pdf (accessed on 23 August 2021).

46. Fuel Cells and Hydrogen Joint Undertaking. Hydrogen Roadmap Europe: A Sustainable Pathway for the European Energy Transition. Available online: https:/ / www.fch.europa.eu/publications/hydrogen-roadmap-europe-sustainable-pathway-europeanenergy-transition (accessed on 18 September 2021).

47. Unterlohner, F. Comparison of Hydrogen and Battery Electric Trucks: Methodology and Underlying Assumptions. Available online: https://www.transportenvironment.org/wp-content/uploads/2021/07/2020_06_TE_comparison_hydrogen_battery_ electric_trucks_methodology.pdf (accessed on 28 July 2021).

48. Thomsen, J. Enhancing operation of decentralized energy systems by a regional economic optimization model DISTRICT. Energy Syst. 2018, 9, 669-707. [CrossRef]

49. Saad Hussein, N. A method for evaluating building retrofit effects on a decentral energy system by a sector coupling operation and expansion model. Energy Syst. 2018, 9, 605-645. [CrossRef]

50. Wanapinit, N.; Thomsen, J.; Kost, C.; Weidlich, A. An MILP model for evaluating the optimal operation and flexibility potential of end-users. Appl. Energy 2021, 282, 116183. [CrossRef]

51. Dess, G.G.; McNamara, G.; Eisner, A.B. Strategic Management: Text and Cases, 9th ed.; McGraw-Hill Education: New York, NY, USA, 2019.

52. United Nations Children's Fund. SWOT and PESTEL: Understanding Your External and Internal Context for Better Planning and Decision-Making. Available online: https://www.academia.edu/30818727/SWOT_AND_PESTEL_Understanding_your_ external_and_internal_context_for_better_planning_and_decision_making_WHAT_ARE_SWOT_AND_PESTEL (accessed on 14 September 2021).

53. European Aggregates Association. Annual Review of European Aggregates Association: A Sustainable Industry for a Sustainable Europe. Available online: https://uepg.eu/mediatheque/media/UEPG-AR20192020_V13_(03082020)_spreads.pdf (accessed on 29 September 2021).

54. Coelho, A.; de Brito, J. Environmental analysis of a construction and demolition waste recycling plant in Portugal-Part I: Energy consumption and $\mathrm{CO}_{2}$ emissions. Waste Manag. 2013, 33, 1258-1267. [CrossRef] [PubMed]

55. EPEX Spot. EEX Prices. Available online: https://www.epexspot.com/en (accessed on 10 October 2021).

56. Wissenschaftliche Dienste des Deutschen Bundestages. Fragen zur Entwicklung der Netzentgelte im Stromsektor. Available online: https:/ / www.bundestag.de/resource/blob/689786/9b84cafbe64abf68170c87763ca2b5ea/WD-5-012-20-pdf-data.pdf (accessed on 5 October 2021). 
57. Bundesverband der Energie- und Wasserwirtschaft. BDEW-Strompreisanalyse Juli 2019: Haushalte und Industrie. Available online: https://cupdf.com/document/bdew-strompreisanalyse-juli-2019-bdew-bundesverband-der-energie-undwasserwirtschaft.html (accessed on 26 August 2021).

58. Kühnel, S.; Hacker, F.; Görz, W. Oberleitungs-Lkw im Kontext weiterer Antriebs- und Energieversorgungsoptionen für den Straßengüterfernverkehr: Ein Technologie- und Wirtschaftlichkeitsvergleich.Available online: https://www.oeko. de/publikationen/p-details/oberleitungs-lkw-im-kontext-weiterer-antriebs-und-energieversorgungsoptionen-fuer-denstrassengueterfe (accessed on 9 September 2021).

59. Fraunhofer ISE. Energy-Charts: The Site for Interactive Graphics Displaying Energy Production and Spot Market Prices, 2020. Available online: https:/ / energy-charts.info/?l=en\&c=DE (accessed on 4 October 2021).

60. Icha, P.; Lauf, T.; Kuhs, G. Entwicklung der Spezifischen Kohlendioxid-Emissionen des Deutschen Strommix in den Jahren 1990-2019. Available online: https:/ / www.umweltbundesamt.de/publikationen/entwicklung-der-spezifischen-kohlendioxid-6 (accessed on 13 September 2021).

61. Fraunhofer ISE. Wege zu Einem Klimaneutralen Energiesystem: Die Deutsche Energiewende im Kontext Gesellschaftlicher Verhaltensweisen. Available online: https:/ /www.ise.fraunhofer.de/de/veroeffentlichungen/studien/wege-zu-einem-klimaneutralenenergiesystem.html (accessed on 12 October 2021).

62. World Bank Group; ESMAP; SERIS. Where Sun Meets Water: Floating Solar Market Report. Available online: https:/ /openknowledge. worldbank.org/handle/10986/31880 (accessed on 10 September 2021).

63. Pfenninger, S.; Staffell, I. Renewables.ninja; 2020. Available online: https://www.renewables.ninja/about (accessed on 10 October 2021).

64. Pfenninger, S.; Staffell, I. Long-term patterns of European PV output using 30 years of validated hourly reanalysis and satellite data. Energy 2016, 114, 1251-1265. [CrossRef]

65. Staffell, I.; Pfenninger, S. Using bias-corrected reanalysis to simulate current and future wind power output. Energy 2016, 114, 1224-1239. [CrossRef]

66. Figgener, J.; Haberschusz, D.; Kairies, K.P.; Wessels, O.; Zurmühlen, S.; Sauer, D.U. Speichermonitoring BadenWürttemberg: Jahresbericht 2019. Available online: https://www.speichermonitoring-bw.de/wp-content/uploads/20 19/08/Speichermonitoring_BW_Jahresbericht_2019_ISEA_RWTH_Aachen.pdf (accessed on 17 September 2021).

67. Cole, W.; Frazier, A.W. Cost Projections for Utility-Scale Battery Storage. Available online: https://www.nrel.gov/docs/fy19osti/ 73222.pdf (accessed on 28 September 2021).

68. Prognos; Fraunhofer UMSICHT; DBFZ. Status und Perspektiven flüssiger Energieträger in der Energiewende. Available online: https://www.umsicht-suro.fraunhofer.de/content/dam/umsicht-suro/de/images/pressemitteilungen/2018 /EndberichtPrognos/Prognos-Endbericht_Fluessige_Energietraeger_Web-final.pdf (accessed on 25 July 2021).

69. Bundesverband Güterkraftverkehr Logistik und Entsorgung. Dieselpreis-Information (Großverbraucher). Available online: https: / / www.bgl-ev.de/images/downloads / dieselpreisinformation.pdf (accessed on 17 September 2021).

70. Umweltbundesamt. $\mathrm{CO}_{2}$-Emissionsfaktoren für fossile Brennstoffe. Available online: https://www.umweltbundesamt.de/sites/ default/files/medien/1968/publikationen/co2-emissionsfaktoren_fur_fossile_brennstoffe_korrektur.pdf (accessed on 23 August 2021).

71. Kreidelmeyer, S.; Dambeck, H.; Kirchner, A.; Wünsch, M. Kosten und Transformationspfade für strombasierte Energieträger: Endbericht zum Projekt Transformationspfade und regulatorischer Rahmen für synthetische Brennstoffe. Available online: https://www.bmwi.de/Redaktion/DE/Downloads/Studien/transformationspfade-fuer-strombasierte-energietraeger. pdf?_blob=publicationFile (accessed on 7 October 2021).

72. Wuester, H.; Jungmin Lee, J.; Lumijarvi, A. Unlocking Renewable Energy Investment: The Role of Risk Mitigation and Structured Finance. Available online: https://www.irena.org/-/media/Files/IRENA/Agency/Publication/2016/IRENA_Risk_Mitigation_ and_Structured_Finance_2016.pdf (accessed on 5 October 2021).

73. Richstein, J.C.; Hosseinioun, S.S. Industrial demand response: How network tariffs and regulation (do not) impact flexibility provision in electricity markets and reserves. Appl. Energy 2020, 278, 115431. [CrossRef]

74. Poplavskaya, K.; de Vries, L. Distributed energy resources and the organized balancing market: A symbiosis yet? Case of three European balancing markets. Energy Policy 2019, 126, 264-276. [CrossRef]

75. WindNODE. Flexibility, Markets and Regulation: Insights from the WindNODE Reality Lab. Available online: https://www. windnode.de/fileadmin/Daten/Downloads/FMR_eng.pdf (accessed on 6 October 2021). 